\title{
Effect of Collective Bargaining Process on Industrial Relations Environment in Public Universities in Kenya
}

\author{
Dr. Patrick J.Akhaukwa \\ Acting Registrar (RIO), \\ Jaramogi Oginga Odinga University of Science and Technology, \\ pakhaukwa2004@yahoo.com (corresponding author) \\ Dr. Loice Maru \\ Senior lecturer, Moi University, \\ Icmaru@yahoo.com \\ Prof. John Byaruhanga \\ Associate Professor, Masinde Muliro University of Science and Technology, \\ johnbyaruhanga@ymail.com
}

Doi:10.5901/mjss.2013.v4n2p275

\section{Abstract}

This article investigates the effect of collective bargaining process on industrial relations environment in public universities in Kenya. The data used in analysis is based on stratified probability sample of 322 respondents interviewed in 2012 in the three public universities in Kenya. Expert judgment was used to determine the validity while Cronbach alpha coefficient was used to determine reliability of research instruments. Qualitative and quantitative data was analyzed using both descriptive and inferential statistics. Exploratory factor analysis was performed to reduce large number of variables for further analysis. Linear regression analysis was employed to determine the effect of collective bargaining process on industrial relations. The result show that collective bargaining process has a significant effect on industrial relations environment $(\beta=0.495, p<0.05)$. It is recommended that parties to collective bargaining should reconsider their strategies' for engagement in order to enhance their relationship.

Key Words: Collective bargaining process, Industrial relations environment, Public universities, Academic staff, Kenya

\section{Introduction}

Industrial relations is one of the key elements in the system of labour administration (Goolsarran, 2006), hence an essential predictor of organization success. A large body of literature on the positive effects of good industrial relations on company performance, efficiency and productivity which underscores the importance of industrial relations in organizational success (Fashoyin, 2004; Pyman et al., 2010). For instance, Silva (1998), observes that sound industrial relations is one in which relationships between management and employees on the one hand, and between them and the State on the other, are more harmonious and cooperative than conflictual. Silva, further maintains that a good industrial relation is one that creates an environment conducive to economic efficiency and the motivation, productivity and development of the employee, and generates employee loyalty and mutual trust. On the other hand, Antonioli et al. (2011) noted that good quality industrial relations emerge as mediating factors that reinforce, in a positive way, the role of innovation activities on workers' well being.

Collective bargaining is central to any industrial relations system since it is a tool through which regulated flexibility is achieved (Godfrey et al., 2007). A number of studies show that where workers had their terms and conditions of employment determined through collective bargaining and where management supported unions, there was an improved industrial relations environment (Edwards, 2002; Beardwell et al., 2004). Adewole et al. (2010) asserted that frequent eruption of industrial conflicts between employers and employees in general can be effectively managed through 
collective negotiation and consultation with the workers' representatives. Collective bargaining has been noted to help promote cooperation and mutual understanding between workers and management by providing a framework for dealing with industrial relations issues without resort to strike and lockouts. Therefore, fair and legal process will result in successful collective bargaining, hence maintenance of industrial discipline and peace and vice-versa (Gomez et al. 2003).

Universities all over the world are considered as centres of excellence which immensely contribute to national development. From theory and practice, it is evident that higher education is critical to political, social, economic, and technological growth of a country. The absence of good industrial relations environment can therefore seriously affect the stability and training programs in universities and hence the overall national development. There has therefore been a great deal of attention surrounding stability of public universities in recent times following the introduction of collective bargaining. So far a detailed examination of how collective bargaining process impacts on industrial relations environment in public universities in Kenya is lacking. The main aim of the paper is to provide such an account.

The analysis rests on the premise that collective bargaining has a significant effect on industrial relations environment. It is hoped that the knowledge gained from this study will contribute to the existing body of knowledge in the area of collective bargaining and industrial relations environment in both public and private sectors in Kenya. It will also shed light and create awareness to employers, employees, trade unions and the government on industrial relations environment issues. The findings will form a basis for policy formulation as well serve as a point of reference for further research.

\section{Industrial Relations Environment}

Industrial relations environment refers to the atmosphere, norms, attitudes and behaviours reflecting and underpinning how workers, unions and managers interact collectively with each other in the workplace, which in turn, affects workplace outcomes (Kersley et al., 2006). According to Pyman et al. (2010), workplace environment and the contextual factors are sometimes described as the industrial relations climate, and this concept has been used to explain behavior and attitudes in the workplace, and interactions between unions, employees and employers. Industrial relations environment therefore depicts the state and quality of union-management relations in an organization. Industrial relations environment can therefore be described as a function of work practices (the organization of work) and employment practices -the management of people, and thus may be linked to organizational performance- company and worker outcomes (Boxall and Macky, 2009).

Some studies have shown that favourable perceptions of industrial relations environment are positively associated with commitment to both the employer and the union. These studies have further indicated that favorable perceptions of the industrial relations environment allows for commitment of employer and employee because of cognitive consistency between the role of employee and union member in workplaces with more cooperative union-management relations (Redman and Snape, 2006). Industrial relations environment has therefore been identified as a key mediating factor in the link between high-performance work systems and organizational performance and effectiveness (Kersley et al., 2006). Other outcomes that have been found to be associated with a favourable industrial relations climate include: positive perceptions of organizational prestige, positive attitudes towards supervisors, reduced absenteeism, turnover and conflict, innovation, customer satisfaction, and service or product quality (Lee, 2009).

According to Khan (2006), a stable industrial relations climate is therefore vitally important for the economic growth of any country. This observation is consistent with a study by Goolsarran (2006) which revealed that the climate of labour and industrial relations in any country has a direct impact on its economic and social development, which requires a favorable environment in which labour relations can be conducted in an orderly and responsible manner.

Pyman et al. (2010) concluded that employees' perceptions of the industrial relations climate are more likely to be favourable if they have access to direct-only voice arrangements. Where management is perceived by employees to oppose unions, the industrial relations climate is more likely to be reported as poor. Wan (1997) therefore identified six dimensions of industrial relations that can be used to measure industrial relations environment namely: union management c-o-operation, mutual regard, apathy, joint participation, hostility and trust. This study will therefore adopt, with modification, Wan's six dimension model to measure industrial relations environment in public universities in Kenya.

\section{Collective Bargaining Process and Industrial Relations Environment}

According to Cole (2002), collective bargaining process begins with the union claim which is followed by an initial counter 
offer from management. Once management's initial response has been made, then negotiation can commence in earnest. Cole further points out that in most cases, a settlement is reached without undue delay and acrimony, and the agreed terms of the settlement are published, implemented and subsequently monitored. Each side has therefore to decide its overall objectives or strategy, asses its relative bargaining strength, and, in the light of that assessment, decide on the tactics to be employed to achieve an optimum result.

According to Aluchio (1998), the process is that the union submits its problem to management in writing within a reasonable time. Hence collective bargaining is a union initiated process and that if employees did not form collectives and demand that employers bargain with them, bargaining might never occur (Bendix, 2001). The process therefore preclude the employer from taking any unilateral action by changing the condition of which bargaining is first required (Hunter, 1999). A study by Trif (2005) revealed that, collective bargaining takes place between a negotiation team consisting of top managers and company trade union representatives. The study points out that on the employer side, the management board appoints the team responsible for collective bargaining. On the employees' side, respondents reported that shop stewards initially have meetings with all members to discuss their demands. Subsequently, union representatives gather to decide the collective bargaining proposal and the negotiation team. Thus, evidence suggests that unions make an effort to find out members' demands, but the procedure used to decide the negotiation teams on both sides is generally top-down.

Gomez et al. (2003), explains that parties are said to be showing good faith in bargaining when; they are willing to meet and confer with each other at a reasonable time and place; they are willing to negotiate over wages, hour and conditions of employment; they sign a written contract that formalizes their agreement and binds them to it; and each party gives the other adequate notice of termination or modification of the labour agreement before it expires. Similarly, there should also be genuine willingness on the part of the parties to 'give and take' at the bargaining table, cooperation and consideration of fairness under the process.

Cole (2002) explains that, the process of negotiating collective agreement does not occur in a vacuum. The aim of the process, so far as employees representatives are concerned, is to achieve a workable relationship with management, found on mutual respect, in which tangible benefits are realized on agreed terms and not just on management's whim. On their part, management representatives see collective bargaining as one method of attaining corporate objectives relating to pay and conduct of employee relations. Collective bargaining is therefore a rational process in which appeal to facts and to logic reconciles conflicting interests in the light of common interest of both parties (Bendix, 2001). Hence, the application of the agreed set of rules to govern the substantive and the procedural terms of employment relationship between the employer and employee will influence industrial relations environment. The amount of trust built up between management and the trade union representatives, in particular, and management and workforce generally, during the process is a major factor in the quality of industrial relations. Where the trust is high, it is less likely that one side or the other will resort to sanctions (Cole, 2002).

Johnstone et al. (2004) revealed that lack of feedback, trust and accountability created tensions between the union representative and employees, hence denting credibility of the process. This can also happen when the employer refuses to engage in meaningful bargaining, by making the first offers final offers and impose changes in terms and conditions rather than negotiate over them as reported in the study by Gall, (2007) on bad faith bargaining,. The study further pointed out that, alternatively, the reluctant employer could engage in "hard-nosed" bargaining where any concessions to the union are self-financing, whereby pay rises are only granted if workforce productivity is increased through redundancies, not filling vacant posts or longer working hours. Gatchalian (1998) suggest that the negotiations should end up without anyone "losing face", feeling bitter and humiliated, or being personally aggrieved. Otherwise the process can develop into a personal confrontation, with each side forgetting the real issues and the main objective.

Collective bargaining process is thus expected to be fair and legal, and should take place in an environment of trust in order for parties to achieve a workable relationship. Collective bargaining process is therefore expected to affect industrial relations environment. The literature shows that collective bargaining process influences the quality of industrial relations. However, the literature decries the lack or limited scholarly contribution on industrial relations from developing nations and more so the African continent (Pyman et al., 2010; Wood, 2008; Wood and Dibben, 2006; and Budhwar, 2003). It is hoped the study will fill this information gap and stimulate more research on industrial relations from this part of the world.

\section{Methodology}

The study used explanatory research design to establish the effect of collective bargaining process on industrial relations 
environment. The universe of the study was academic staff who were members of Universities Academic Staff Union (UASU) from universities in Kenya. The population was stratified by designations to reflect the distribution of various categories of academic staff and a total of 322 respondents were selected using simple random sampling from three public universities. Academic staff who were holding managerial positions, those on study leave or leave of absence and those serving on contractual terms were excluded from the study. The research was conducted between April and July 2012.

The survey instrument was adopted from the 2010 Industrial Relations Climate, Employee Voice and Managerial Attitudes to Unions Survey conducted in Australia (Pyman et al., 2010), Industrial Relations Climate Survey in the Manufacturing sector in Singapore (Wan et al., 1997) and Industrial Relations Climate and Staff Survey in the Fire Service in United Kingdom (Redman and Snape, 2006). Original questions from the above studies were modified to conform to the objective of the study and to take into consideration the Kenyan contexts. Using the pilot data, the reliability of 0.8899 and 0.8115 was established for the instruments. The reliability was calculated using Cronbach's Coefficients Alphas.

The dependent variable was based on responses on eight items which were rated on a five point Likert type scale ranging from " $1=$ strongly disagree" to " $5=$ strongly agree", with " 3 " being a neutral midpoint. The following eight measures guided this study in assessing the industrial relations environment: management union cooperation, mutual regard for each other, willingness of the parties to confer, willingness of management to facilitate union operations, joint participation in decision making, dispute resolution and management attitude towards the union. In addition, collective bargaining was assessed on eight items namely; fairness of the process, willingness of management to negotiate, and time taken to reach an agreement. Others were concern for others view point, spirit of give and take, degree of members' participation and implementation of the agreed terms The respondents were asked to indicate the degree of satisfaction with collective bargaining process on a five point Likert type scale ranging from " $1=$ extremely dissatisfied" to " $5=$ extremely satisfied".

The data was analyzed to provide frequencies, percentages, means and standard deviation to describe the population. Both independent and dependent variables were exposed to factor analysis to reduce large number of explanatory variables and screen variables for further analysis. Factor scores from factors with eigenvalues greater than one were considered as dependent and independent variables. Regression analysis was used to determine the effect of collective bargaining process on industrial relations environment in public universities in Kenya.

\section{Findings}

\subsection{Industrial Relations Environment}

As illustrated in Table 1, the findings of this study revealed that majority $(67.7 \%, \mathrm{f}=218)$ of respondents strongly disagreed or disagreed that union and management cooperates well while $13 \%(f=42)$ were neutral. A further $19.3 \%(f=62)$ strongly agreed or agreed that union and management cooperates well at work. Majority $(66.7 \%, f=214)$ of respondents strongly disagreed or disagreed that mutual regard existed between management and union, $19.3 \%(\mathrm{f}=62)$ were neutral while $14 \%(f=45)$ strongly agreed or agreed.

Table 1 Analysis of the Items on Industrial Relations Environment

\begin{tabular}{cccccccccc}
\hline & \multicolumn{9}{c}{ Rating } \\
Item & $\mathrm{SD} \%(\mathrm{~F})$ & $\mathrm{D} \%(\mathrm{~F})$ & $\mathrm{N} \%(\mathrm{~F})$ & $\mathrm{A} \%(\mathrm{~F})$ & $\mathrm{SA} \%(\mathrm{~F})$ & $\mathrm{M}$ & $\mathrm{SD}$ & $\mathrm{S}$ & $\mathrm{K}$ \\
A1 & $17.1(55)$ & $50.6(163)$ & $13.0(42)$ & $17.4(56)$ & $1.9(6)$ & 2.36 & 1.018 & .652 & -.391 \\
A2 & $7.8(25)$ & $58.9(189)$ & $19.3(62)$ & $12.1(39)$ & $1.9(6)$ & 2.41 & .869 & .897 & .469 \\
A3 & $9.3(30)$ & $62.1(200)$ & $12.4(40)$ & $14.6(47)$ & $1.6(5)$ & 2.37 & .898 & .941 & .321 \\
A4 & $19.4(62)$ & $57.8(185)$ & $12.5(40)$ & $8.4(27)$ & $1.9(6)$ & 2.16 & .896 & 1.029 & 1.110 \\
A5 & $13(42)$ & $57.5(191)$ & $15.2(49)$ & $11.8(38)$ & $2.5(8)$ & 2.33 & .933 & .913 & .504 \\
A6 & $16.2(52)$ & $59.5(146)$ & $14.6(47)$ & $9.3(30)$ & $0.3(1)$ & 2.18 & .824 & .798 & .516 \\
A7 & $20.2(65)$ & $45.5(146)$ & $15.0(48)$ & $15.9(51)$ & $3.4(11)$ & 2.37 & 1.079 & .653 & -.379 \\
A8 & $12.7(41)$ & $53.4(172)$ & $13.0(42)$ & $19.3(62)$ & $1.6(5)$ & 2.43 & .991 & .627 & -.483 \\
\hline
\end{tabular}

$n=322$.

Source: Survey data 2012 
Key:

$\mathrm{SD}=$ strongly disagree; $\mathrm{D}=$ disagree; $N=$ neither; $\mathrm{A}=$ =agree; $\mathrm{SA}=$ strongly agree;

$\mathrm{M}=$ =mean; $\mathrm{SD}=$ standard deviation; $\mathrm{S}=$ skewness; $\mathrm{K}=$ kurtosis; $\mathrm{F}=$ frequency

$A 1=$ Union and management cooperates well, $A 2=$ Mutual regard between management and the union exist, $A 3=$ Union and management are willing to confer; $A 4=$ Management facilitates union operations; $A 5=$ Union participates in decision making; $A 6=$ Management and union resolve disputes amicably; $A 7=$ Management's attitude towards the union is favourable; $A 8=$ Management and union share information freely

On the other hand, $71.4 \%(\mathrm{f}=230)$ of the respondents strongly disagreed or disagreed that union and management are willing to confer, while $12.4 \%$ ( $f=40$ ) were neutral and $16.2 \%(f=52)$ strongly agreed or agreed. Further, $77.2 \%(f=247)$ of the strongly disagreed or disagreed that management facilitates union operations, $12.5 \%(f=40)$ were neutral and 10.3 $\%(f=33)$ strongly agreed or agreed with the above statement. Likewise, $70.5 \%(f=227)$ of the respondents strongly disagreed or disagreed that union was involved in decision making while $15.2 \%$ ( $f=49)$ were neutral. Further $14.4 \%(f=46)$ indicated that they strongly agreed or agreed that union participated in decision making.

On dispute resolution, an overwhelming majority $(75.7, \mathrm{f}=243)$ strongly disagreed or disagreed that management and the union resolve disputes amicably, $14,6 \%(\mathrm{f}=47)$ were neutral and $9.6 \%(\mathrm{f}=31)$ strongly agreed or agreed. In addition, $65.7 \%$ ( $f=211$ ) strongly disagreed or disagreed that management's attitude towards the union was favourable, $15 \%(f=48)$ were neutral while $19.3 \%(f=62)$ strongly agreed or agreed with the above statement. On sharing of information, $66.1 \%(\mathrm{f}=213)$ strongly disagreed or disagreed that union and management share information freely, while $13 \%(f=42)$ were neutral. Another $20.9 \%(f=67)$ of respondent strongly agreed or agreed that union and management share information freely.

Table 2: Overall Scores on Industrial Relations Environment

\begin{tabular}{lcc}
\hline Rating & Frequency & Percent \\
Poor & 176 & 54.7 \\
Neither & 129 & 40.1 \\
Good & 17 & 5.3 \\
Total & 322 & 100.0 \\
Mean & 1.51 & \\
Std. Deviation & .597 & \\
\hline $\mathrm{n}=322$ & &
\end{tabular}

Source: Survey Data 2012

In the overall analysis as indicated in Table 2 , most $(54.7 \%, \mathrm{f}=176)$ of the respondents indicated that industrial relations environment was poor. On the other hand only $5.3 \%(f=17)$ reported that the industrial relations was good and $40 \%$ ( $f=129$ ) were neutral. The study found the mean score on industrial relations environment to be 1.51 with a standard deviation of 0.597 .

These results were interpreted to mean that majority of academic staff in public universities felt that management and the union do not cooperate well neither did they confer with each other nor solve disputes amicably. Also, they thought that management did not facilitate the operations of the union, mutual regard did not exist among the parties, and management's attitude towards the union was not favorable. Besides, union did not actively participate in decision making at their place of work and management and the union did not share information freely. Overall, the result was interpreted to mean that academic staff perceived the industrial relations environment in public universities as poor.

\subsection{Factor Analysis for Industrial Relations Environment}

Exploratory factor analysis was applied to industrial relations environment variables to identify components underlying the variables. The analysis was preceded by Kaiser-Meyer-Olkin (KMO) and Bartlett's test for sphericity in order to establish the sampling adequacy for satisfactory factor analysis to proceed. The KMO measure greater than 0.5 and significant 
Bartlett's test is acceptable for factor analysis (Field, 2000). The Bartlett's test of sphericity was significant $(p<0.05)$ and KMO (.806) was greater than 0.5 .

An analysis was then done to establish component score coefficients, component loading and communality. Data in Table 3 shows all components extracted from the analysis along with their component score coefficients, rotated component loading and communalities.

The values of the loading and corresponding components indicate correlations between variables and corresponding components. As shown in Table 3 , it is apparent that the following variables are substantially loaded on component 1; union and management cooperates well, mutual regard between management and the union exists, union and management are willing to confer, union participates in decision making and management and union resolve disputes amicably. This suggests that these five variables define component. On the other hand, management attitude towards the union is favourable and management and the union share information freely are highly loaded on component 2 hence they define component 2 . These two components explain the industrial relations environment.

Table 3: Result of Factor Analysis on Industrial Relations Environment Variables

\begin{tabular}{lccccccc}
\hline & \multicolumn{2}{c}{$\begin{array}{c}\text { Component } \\
\text { Score }\end{array}$} & \multicolumn{3}{c}{$\begin{array}{c}\text { Rotated Component } \\
\text { Loading and }\end{array}$} \\
& \multicolumn{2}{c}{ Coefficient } & \multicolumn{3}{c}{ Communalities } \\
& $\mathrm{C}_{1}$ & $\mathrm{C}_{2}$ & $\mathrm{C}_{1}$ & $\mathrm{C}_{2}$ & $\mathrm{Com}$. \\
Union and management cooperates well & .259 & -.061 & .705 & .200 & .537 \\
Mutual regard between management and the union exist & .319 & -.147 & .778 & .101 & .615 \\
union and management are willing to confer & .333 & -.175 & .784 & .061 & .618 \\
Management facilitates union operations & .101 & .186 & .536 & .503 & .540 \\
Union participates in decision making & .226 & -.001 & .677 & .278 & .536 \\
Management and union resolve disputes amicably & .222 & .025 & .698 & .327 & .594 \\
Management attitude towards the union is favourable & -.149 & .520 & .199 & .868 & .793 \\
Management and the union share information freely & -.182 & .548 & .135 & .884 & .800 \\
\hline
\end{tabular}

Source: Survey Data 2012

\section{Key: $\mathrm{C}_{1}=$ Component $1 ; \mathrm{C}_{2}=$ Component 2 ; Com=Communalities}

The values of communalities show how much of the variance in the variable has been accounted for by extracted factors. Table 3 shows that communality for management attitude towards the union is favourable was $79.3 \%$, indicating that $79.3 \%$ of variance in management attitude towards the union is accounted for by Component 1 and 2 . Similarly, 80\% of the variance in management and union share information freely was accounted for by Component 1 and 2.

Analysis of total variance was then done to determine the proportion of variance in the set of variables. Table 4 shows all components extracted from the analysis along with their Eigenvalues, the percentage of variance attributed to each component, and the cumulative variance of the component and the previous components. The table indicates that two out of eight components had Eigenvalues greater than 1. In addition, the table shows that the first component accounts for $48.18 \%$ of the variance in the variables and the second component $14.725 \%$. All the remaining components are not significant. The two selected components explained $62.906 \%$ of the total variation of the variables in industrial relations environment. Component score coefficients in Table 3, were used to obtain component score values. The mean scores of component score values for the retained two components were then used as dependent variable $(\mathrm{Y})$ in regression analysis to determine the effect of independent variables on industrial relations environment. 
Table 4: Total Variance Explained

\begin{tabular}{cccccccccc}
\hline C & \multicolumn{3}{c}{ Initial Eigenvalues } & \multicolumn{3}{c}{ Extraction Sums of Squared } & \multicolumn{3}{c}{ Rotation Sums of Squared } \\
& Total & $\%$ of V & CU\% & Total & \% of V & CU \% & Total & $\%$ of V & CU \% \\
1 & 3.854 & 48.180 & 48.180 & 3.854 & 48.180 & 48.180 & 3.007 & 37.588 & 37.588 \\
2 & 1.178 & 14.725 & 62.906 & 1.178 & 14.725 & 62.906 & 2.025 & 25.318 & 62.906 \\
3 & .831 & 10.390 & 73.296 & & & & & & \\
4 & .622 & 7.771 & 81.067 & & & & & & \\
5 & .530 & 6.629 & 87.696 & & & & & & \\
6 & .370 & 4.630 & 92.326 & & & & & & \\
7 & .333 & 4.166 & 96.492 & & & & & & \\
8 & .281 & 3.508 & 100.000 & & & & & & \\
\hline
\end{tabular}

Source: Survey Data 2012

Key: $\mathrm{V}=$ variance; $\mathrm{CU}=$ cumulative; $\mathrm{C}=$ component

\subsection{Collective Bargaining Process and Industrial Relations Environment}

An analysis of items on collective bargaining process was performed based on eight items which were scored on a five point Likert type scale ranging from " $1=$ extremely dissatisfied" to " $5=$ extremely satisfied", with "3" being a neutral midpoint. Table 5 presents the results of this analysis.

Table 5 Analysis of items on Collective Bargaining Process

\begin{tabular}{cccccccccc}
\hline & & & & Rating & & & & \\
Item & EDS $\%(\mathrm{~F})$ & $\mathrm{DS} \%(\mathrm{~F})$ & $\mathrm{N} \%(\mathrm{~F})$ & $\mathrm{S} \%(\mathrm{~F})$ & $\mathrm{ES} \%(\mathrm{~F})$ & $\mathrm{M}$ & $\mathrm{SD}$ & $\mathrm{S}$ & $\mathrm{K}$ \\
$\mathrm{C} 1$ & $25.2 \%(81)$ & $50.6 \%(163)$ & $14.3 \%(46)$ & $9.6 \%(31)$ & $.3 \%(1)$ & 2.09 & .895 & .734 & .077 \\
C2 & $14.6 \%(47)$ & $63.2 \%(203)$ & $12.5 \%(40)$ & $9.7 \%(31)$ & $0 \%(0)$ & 2.17 & .794 & .854 & .616 \\
C3 & $14.7 \%(47)$ & $67.4 \%(215)$ & $10.3 \%(33)$ & $6.9 \%(22)$ & $.6 \%(2)$ & 2.11 & .756 & 1.126 & 1.970 \\
C4 & $12.5 \%(40)$ & $64.7 \%(207)$ & $17.5 \%(56)$ & $4.7 \%(15)$ & $.6 \%(2)$ & 2.16 & .720 & .911 & 1.732 \\
C5 & $8.1 \%(26)$ & $57.0 \%(183)$ & $26.8 \%(86)$ & $7.5 \%(24)$ & $.6 \%(2)$ & 2.36 & .761 & .669 & .563 \\
C6 & $12.5 \%(40)$ & $55.6 \%(178)$ & $14.7 \%(47)$ & $16.3 \%(52)$ & $.9 \%(3)$ & 2.37 & .932 & .684 & -.238 \\
C7 & $5.6 \%(18)$ & $39.4 \%(127)$ & $24.2 \%(78)$ & $30.1 \%(97)$ & $.6 \%(2)$ & 2.81 & .954 & .047 & -1.155 \\
C8 & $14.1 \%(45)$ & $56.6 \%(181)$ & $15.0 \%(48)$ & $14.1 \%(45)$ & $.3 \%(1)$ & 2.13 & .891 & .685 & -.136 \\
\hline $\mathrm{n=322}$ & & & & & & & & &
\end{tabular}

Source: Primary Data, 2012

Key:

$E D=$ extremely dissatisfied; $D S=$ dissatisfied; $N$ =neutral; $S=$ satisfied;

$\mathrm{ES}=$ extremely satisfied; $\mathrm{M}=$ mean; $\mathrm{SD}=$ standard deviation; $\mathrm{S}=$ skewness;

$\mathrm{K}=$ kurtosis; $\mathrm{F}=$ frequency, $\mathrm{C} 1=$ Fairness of the process, $\mathrm{C} 2=$ Willingness of management to

Negotiate, C3= Time taken to reach an agreement, C4=Concern for other parties view point, C5=

Willingness to give and take, $\mathrm{C} 6=$ Degree of feedback given to members,

$\mathrm{C} 7=$ Degree of members participation, $\mathrm{C} 8=$ Implementation of agreed terms

The study found that the majority $(75.8 \%, \mathrm{f}=244)$ of respondents were extremely dissatisfied or dissatisfied with the fairness of the collective bargaining process while $9.9 \%$ ( $f=32$ ) were extremely satisfied or satisfied and $14.3 \%$ ( $f=46$ ) were neutral. Further, overwhelming $77.8 \%(f=250)$ of the respondent indicted that they were extremely dissatisfied or dissatisfied with the willingness on the part of management to negotiate with the union. Only $9.7 \%, f=31$ ) reported that they were extremely satisfied or satisfied and $12.5 \%(f=40)$ were neutral. 
On the item regarding time taken before a collective bargaining agreement was reached, $82 \%(f=262)$ indicated that they were extremely dissatisfied or dissatisfied, $10.3 \%(f=33)$ were neutral while only $7.5 \%(f=24)$ said that were extremely satisfied or satisfied. In addition, $77 \%(\mathrm{f}=247)$ indicated that they were extremely dissatisfied or dissatisfied with parties concern for each other's point of view while $17.5 \%$ ( $f=56$ ) were neutral and only $5.3 \%(f=17)$ reported that they were extremely satisfied or satisfied. Further, $65.1 \%(f=209)$ said that they were extremely dissatisfied or dissatisfied with the willingness for the parties to give and take as opposed to $8.1 \%(\mathrm{f}=26)$ who reported that they were extremely satisfied of satisfied, while $26.8 \%(\mathrm{f}=86)$ were neutral.

Regarding feedback to members, the study revealed that $68.1 \%(f=218)$ were extremely dissatisfied or dissatisfied with the degree of feedback given to members compared to $17.2 \%(f=55)$ who pointed out that they were extremely satisfied or satisfied. Only $14.7 \%$ ( $f=47)$ percent said that they were neutral on the degree of feedback given to members. Also, $45 \%$ ( $f=145$ ) reported that they were extremely dissatisfied or dissatisfied with the degree of members' participation as opposed to $30.7 \%$ ( $f=99)$ who indicated that they were, extremely satisfied or satisfied and $24.8(f=78)$ who said that they were neutral. On implementation of agreed terms, $70 \%$ of the respondents said that they were extremely dissatisfied or dissatisfied while $14.4 \%(f=46)$ were extremely satisfied or satisfied and $15.0 \%(f=48)$ were neutral.

These results were interpreted to signify that academic staff were dissatisfied with time taken to negotiate a collective bargaining agreement and the willingness of management to negotiate. Besides, they were dissatisfied with fairness of the process, concern of other party point of view and willingness to give and take. In addition, academic staff were not satisfied with the degree of feedback and members participation in the process. Finally, they were dissatisfied with the implementation of agreed terms.

Table 6: Overall Scores on Collective Bargaining Process

\begin{tabular}{lcc}
\hline Rating & Frequency & Percent \\
Dissatisfied & 194 & 60.2 \\
Neither & 121 & 37.6 \\
Satisfied & 7 & 2.2 \\
Total & 322 & 100.0 \\
Mean & 1.42 & \\
Std. Deviation & .537 & \\
\hline $\mathrm{n}=322$ & &
\end{tabular}

Source: Survey Data, 2012

In the overall analysis as indicated in Table 6 majority $(60.2 \%, \mathrm{f}=194)$ of academic staff reported that they were dissatisfied with collective bargaining. An insignificant $2.2 \%(f=7)$ indicated that they were satisfied with the collective bargaining process while $34.5 \%$ (111) reported that they were neutral. The study further found the mean score on collective bargaining process to be 1.42 with a standard deviation of 0.537 . This result was interpreted to signify that academic staff were dissatisfied with collective bargaining process in public universities.

\subsection{Factor Analysis for Collective Bargaining Process}

Exploratory factor analysis was applied to collective bargaining process variables to identify components underlying the variables. The analysis was preceded by Kaiser-Meyer-Olkin (KMO) and Bartlett's test for sphericity to establish the sampling adequacy for satisfactory factor analysis to proceed. The result of the test the Bartlett's test of sphericity was significant $(p<0.05)$ and $\mathrm{KMO}(.779)$ was greater than 0.5 .

An analysis was then done to establish components score coefficients, component loading and communality. As demonstrated in Table 7, it is evident that the following variables are substantially loaded on Component 1; willingness of management to negotiate, fairness of the process, concern for other parties view point and time taken to reach an agreement. Hence component 1 is defined by these variables. On the other hand, degree of members' participation, willingness to give and take and the degree of feedback given to members are highly loaded on Component 2 . These variables define component 2 . 
Table 7: Result of Factor Analysis for Collective Bargaining Process

\begin{tabular}{lcccccc}
\hline $\mathrm{C}$ & Component Score Coefficient & \multicolumn{3}{c}{ Rotated Component Loading and } \\
Communalities
\end{tabular}

Source: Survey Data, 2012

Key: $\mathrm{C} 1=$ component $1 ; \mathrm{C} 2=$ component 2 ; Com=Communality

The values of communalities show how much of the variance in the variable has been accounted for by extracted factors. For instance, the Table 7 shows that communality for degree of members' participation was $75.8 \%$, indicating that $75.8 \%$ of variance in degree of members' participation was accounted for by Component 1 and 2 . Similarly, $61.7 \%$ of the variance in willingness of management to negotiate was accounted for by Component 1 and 2 .

Analysis of total variance was then done to determine the proportion of variance in the set of variables. Table 8 shows all components extracted from the analysis along with their Eigenvalues, the percentage of variance attributed to each component, and the cumulative variance of the component and the previous components. The table shows that two out of eight components had Eigenvalues greater than 1. In addition, the table shows that the first component accounts for $39.213 \%$ of the variance and the second component $15.613 \%$. All the remaining components are not significant. The two selected components explained $54.826 \%$ of the total variation of the variables in collective bargaining process.

Component score coefficients in Table 7 were used to obtain component scores values. The mean scores of component score values for the retained two components were then used as independent variable $(X)$ in regression analysis to determine the effect of collective bargaining process on industrial relations environment.

Table 8: Total Variance Explained

\begin{tabular}{|c|c|c|c|c|c|c|c|c|c|}
\hline \multirow[t]{2}{*}{ C } & \multicolumn{3}{|c|}{ Initial Eigenvalues } & \multirow{2}{*}{$\begin{array}{l}\text { Extraction } \\
\text { Loadings } \\
\text { Total }\end{array}$} & \multirow{2}{*}{$\begin{array}{l}\text { Sums of } \\
\% \text { of } \mathrm{V}\end{array}$} & \multirow{2}{*}{$\begin{array}{l}\text { Squared } \\
\mathrm{Cu} \%\end{array}$} & \multicolumn{3}{|c|}{ Rotation Sums of Squared Loadings } \\
\hline & Total & $\%$ of $\mathrm{V}$ & Cum \% & & & & Total & $\%$ of $\mathrm{V}$ & $\mathrm{Cu} \%$ \\
\hline 1 & 3.137 & 39.213 & 39.213 & 3.137 & 39.213 & 39.213 & 2.601 & 32.513 & 32.513 \\
\hline 2 & 1.249 & 15.613 & 54.826 & 1.249 & 15.613 & 54.826 & 1.785 & 22.314 & 54.826 \\
\hline 3 & .906 & 11.331 & 66.157 & & & & & & \\
\hline 4 & .762 & 9.531 & 75.688 & & & & & & \\
\hline 5 & .572 & 7.145 & 82.833 & & & & & & \\
\hline 6 & .545 & 6.812 & 89.646 & & & & & & \\
\hline 7 & .446 & 5.575 & 95.221 & & & & & & \\
\hline 8 & .382 & 4.779 & 100.000 & & & & & & \\
\hline
\end{tabular}

Source: Survey Data 2012.

Key: $\mathrm{V}=$ variance; $\mathrm{CU}=$ cumulative; $\mathrm{C}=$ component 


\section{Result of Regression Analysis}

Regression analysis was performed to determine the effect of collective bargaining on industrial relations environment. In regression analysis, the component mean score values for retained two components of industrial relations environment were regressed against the component mean score values of the retained components of collective bargaining process.

The results in Table 9 demonstrate that collective bargaining process had a significant effect on industrial relations environment $(\beta=0.495, p<0.05)$. Also, collective bargaining process made a positive contribution to industrial relations environment. Therefore the null hypothesis is rejected. This means that collective bargaining process has a positive effect on industrial relations environment in public universities in Kenya.

Table 9: Regression analysis of industrial relations environment and collective bargaining process

\begin{tabular}{|c|c|c|c|c|c|c|c|}
\hline & \multicolumn{2}{|c|}{$\begin{array}{l}\text { Unstandardized } \\
\text { Coefficients }\end{array}$} & \multirow{2}{*}{$\begin{array}{c}\text { Standardized } \\
\text { Coefficients } \\
\text { Beta }\end{array}$} & \multirow[t]{2}{*}{$t$} & \multirow{2}{*}{ Sig. } & \multicolumn{2}{|c|}{ Collinearity Statistics } \\
\hline & B & Std. Error & & & & Tolerance & VIF \\
\hline (Constant) & .002 & .035 & & .065 & .948 & & \\
\hline$x$ & .492 & .049 & .495 & 10.042 & .000 & 1.000 & 1.000 \\
\hline
\end{tabular}

a. Dependent Variable: $Y$

Source: Survey data 2012,

\section{Discussions}

The objective of this study was to establish the effect of collective bargaining process on industrial relations environment in public universities in Kenya. The study found that academic staff felt that union and management did not cooperate well neither did they have mutual regard of each other nor were they willing to confer. Besides, management did not facilitated union's operation and its attitude to the union was not favorable. Similarly, management and the union did not resolve disputes amicably or share information freely, and union did not participate in decision making. Hence, the industrial relations environment in the three public universities where the study was conducted was found to be poor (mean $=1.51, \mathrm{SD}=0.597$ ).

The result of the study further indicated that respondents were dissatisfied with collective bargaining process in public universities (mean=1.42, SD=0.53). They were dissatisfied especially with the time taken to reach an agreement and the fairness of the process. Other issues that respondents were dissatisfied with included the willingness on the part of the employer to negotiate, concern for other party's point of view and implementation of agreed teams. Academic staff were also discontented with the spirit of willingness to give and take, the degree of members' participation and feedback. The study further revealed that collective bargaining process had a significant effect on industrial relations environment in public universities in Kenya $(\beta=0.495, p<0.05)$. Also, collective bargaining made a significant (and positive) contribution to industrial relations environment. This implies that a flawed process that is perceived to be unfair is likely to result in poor industrial relations environment and vice versa.

These results are supported by the literature which has demonstrated evidence of relationship between industrial relations environment and collective bargaining process (Gomez et al., 2003; Johnstone et al., 2004; Fashoniy, 2004; Cole 2002; Trif, 2005). For collective bargaining to be effective, and therefore industrial relation environment, parties to collective bargaining must satisfy themselves with the above aspects of collective bargaining process. For instance, a study by Johnstone et al. (2004), found that lack of feedback, trust and accountability created tensions between the union representatives and employees, hence denting credibility of the process. On the other hand Gomez et al. (2003) points out that the benefits of fair and legal process is successful collective bargaining, hence maintenance of industrial discipline and peace, and vice-versa. Further, Cole (2002) observes that a collective bargaining agreement should be reached without undue delay and acrimony, and the agreed terms of the settlement should be published, implemented and subsequently monitored. In addition, there should be genuine willingness on the part of the parties to 'give and take' at the bargaining table, cooperation and consideration of fairness under the process (Gomez et al. (2003). 


\section{Conclusion}

On the basis of these findings it is evident that collective bargaining process had a positive significant effect on industrial relations environment in public universities in Kenya. The results therefore confirm the validity of the premise that collective bargaining process has a significant effect on industrial relations environment. The study demonstrated that academic staff were dissatisfied with collective bargaining process in public universities. This scenario could be reversed if: one, parties embraces the spirit of give and take, fairness, commitment and timely implementation of agreement and, two, if management and union officials endeavor to acquire negotiation skills and knowledge in labour relations matters so as to improve the process The study therefore reaffirms that understanding how parties handle collective bargaining process, is very critical in determining industrial relations environment in organisations. The research therefore contributes to advancement of knowledge on industrial relations from the African context and particularly on universities in Kenya.

\section{References}

Adewole, O.A. \& Adebola, O. G. (2010). Collective bargaining as a strategy for industrial conflict management in Nigeria". Journal for Research in National Development, 8.1, 326-339

Aluchio, L.P.A. (1998). Trade unions in Kenya. Nairobi: Jomo Kenyatta Foundations.

Antonioli, D., Mazzanti M. \& Pini P. (2011). Innovation, industrial relations and employee outcomes: evidence from Italy". Journal of Economic Studies, 38 .1, 66-90.

Bendix, S. (2011). Industrial relations in South Africa; commonality, conflict and power in collectivebargaining. Available: http://www.books.google.co.ke/books (October 20, 2012).

Boxall, P. \& Macky, K. (2009). Research and theory on high-performance work systems: progressing the high-involvement stream. HumanResource Management Journal, 19.1, 3-23

Budhwar, P. S. (2003). Employment relations in India. Journal of Industrial Relations, 25.2, 132-148.

Beardwell, I., Holden L., \& Clayton, T. (2004). Human resource management: A contemporary approach. (4th Ed.). London: Pearson Education Itd.

Cole, G. A. (2002). Personnel and Human Resource Management. London: Book Power Thomson Learning.

Edwards, P. (2002). Impact of collective bargaining on workplace performance. Available: http://www.europa.eu/eiro/index.htm (October,6 2010)

Fashoyin, T. (2004).Tripartite cooperation, social dialogue and national development. International Labour Review, 143, 343372.

Gall, G. (2007). Turning full circle? Changing industrial relations in the magazine industry in Britain. Personnel Review, 36. 1, 91108.

Gatchalian, J. C. (1998). Principled negotiations - a key to successful collective bargaining. Management Decision, 36.4, $222-$ 225.

Godfrey, S., Theron J. \& Visser M. (2007). The state of collective bargaining in South Africa: An empirical and conceptual study of collective bargaining. Labour Policy and Enterprise Policy Research Group, Working Paper 07/130 University of Cape Town.

Gomez-Mejia, Luis R., Balkin, D. B. \& Cardy R. L. (2003). Managing human resources. Delhi India: Pearson Education.

Goolsarran, S. J. (2006). Industrial Relations in the Caribbean, Issues and Perspectives. International Labour Organization.

Hunter, R.P. (1999). Michigan labour laws: What every employee should know. Available: http:/www.macknac.org/article (June 4, 2010).

Johnstone, S., Wilkinson, A. \& Ackers P. (2004). "Partnership paradoxes: A case study of energy company." Employee Relations, 26. 4, 353-376.

Kersley, B., et al. (2006). Inside the workplace: Findings from the 2004 workplace employment relations survey (WERS). London: Routledge.

Khan, A. M. (2006). Adjudication in industrial disputes - the case of Trinidad and Tobago. ILO.

Lee, J. \& Lee, D. (2009). Labor-management partnership at Korean firms: Its effects on organizational performance and industrial relations quality. Personnel Review,38 .4, 432-452.

Pyman, A., Holland, P., Teicher, J., \& Cooper, B. K. (2010). "Industrial relations climate, employee voice and managerial attitudes to unions: An Australian Study." Journal of Industrial Relations ,48.2, 460-480

Redman, T. R., \& Snape, E. (2006). Industrial relations climate and staff attitudes in the fire Service: A Case of union renewal? Employee Relations, 28. 1, 26-45.

Silva, S.R. (1998). Elements of a sound industrial relations system. East Asia multidisciplinary advisory team.ILO: Bangkok. 
Trif, A. (2005). Collective bargaining practices in Eastern Europe: case study evidence from Romania. Avaialble: http://www.mpifg.de/pu/workpap/wp05-9/wp05-9.html (February 15, 2011).

Wan, D., Haut, O. C, \& Yuee, L. H. (1997). Industrial Relations climate in the manufacturing sector in Singapore. Journal of Management, 14, 123-141.

Wood, G. (2008). Introduction: Employment relations in Africa. Employee Relations, 30 .4, 329-332.

Wood, G. \& Dibben, P. (2006). Coverage of Africa-related studies in international journals: Greater exposure for public intellectuals in sociology and industrial relations."African Sociological Review, 10. 1,180-92. 